\title{
Incidence and Risk Analysis of Surgical Site Infection in Spine Surgery Patients in an Outpatient versus Hospital Cohort
}

\author{
KR Chin ${ }^{1,2,3}$, FJR Pencle ${ }^{4}$, CF Packer ${ }^{4}$, NT Britton ${ }^{4}$, AV Coombs ${ }^{4}$, RF Douglas ${ }^{4}$, JA Seale ${ }^{4}$
}

\begin{abstract}
Objective: Surgical site infection (SSI) is a well-documented cause of patient morbidity, with an associated increase in cost to the healthcare system. The move to outpatient surgery is to reduce the overall cost of surgery in conjunction with improved patient morbidity. The authors aim to determine the incidence of SSIs in the outpatient setting and associated risk factors. This information will prove to be invaluable to overall patient care.

Methods: The databases of 2205 spinal procedures performed over 10 years by a single surgeon were reviewed. Two groups were created; Group 1 patients with procedures performed in the hospital setting and Group 2 patients with procedures performed in the ambulatory surgery centre. Excluded cases were patients under 18 years old, acute trauma and minor orthopaedic procedures. Included cases were cervical fusions, disc replacement and lumbar decompressions with or without fusion. Outcomes assessed included; age, body mass index (BMI), surgeon time and estimated blood loss $(E B L)$. Relative risk factors such as BMI, smoking, alcohol use and a number of spinal levels operated on were also assessed as independent risk factors for SSIs.

Results: There were 1010 included cases, 642 in a hospital setting and 368 in an outpatient setting. Mean age and BMI were $53 \pm 0.5$ years and $28.3 \pm 0.3 \mathrm{~kg} / \mathrm{m}^{2}$, respectively, with no intergroup significance. Surgical times of $217 \pm 11$ minutes and $117 \pm 8$ minutes and EBL of $323 \pm 33 \mathrm{~mL}$ and $73 \pm 8$ $m L$ demonstrated significance $(\mathrm{p}=0.001)$ between the hospital and outpatient group. The overall incidence of SSIs was $1.6 \%$ and there was a significant intergroup difference, $\mathrm{p}=0.045$. Obesity and multilevel surgeries proved to be significant independent risk factors, $\mathrm{p}=0.005$ and $\mathrm{p}=0.01$, respectively. Smoking had the highest relative risk 10.9 and was also significant, $\mathrm{p}=0.02$.

Conclusion: Incidence rate of SSIs in this study showed significant difference between inpatient and outpatient setting. Modifiable risk factors such as weight, smoking, alcohol use and numbers of levels necessary for operation should be considered. This will impact preoperative patient selection, the procedure required and allow for a decrease in SSI risk.
\end{abstract}

Keywords: Incidence, inpatient, less exposure surgery, outpatient, risk analysis, surgical site infections

\section{Análisis de la incidencia y riesgo de infección del sitio quirúrgico en pacientes de cirugía de columna vertebral en una cohorte ambulatorio frente a una hospitalaria}

\author{
KR Chin ${ }^{1,2,3}$, FJR Pencle ${ }^{4}$, CF Packer ${ }^{4}$, NT Britton ${ }^{4}$, AV Coombs ${ }^{4}$, RF Douglas ${ }^{4}$, JA Seale
}

\section{RESUMEN}

Objetivo: Infección del sitio quirúrgico (ISQ) es una causa bien documentada de morbilidad de los

From: ${ }^{1}$ Charles E. Schmidt College of Medicine at Florida Atlantic University, USA, ${ }^{2}$ Herbert Wertheim College of Medicine at Florida International University, USA, ${ }^{3}$ Less Exposure Surgery Specialists Institute (LESS Institute), USA and ${ }^{4}$ Less Exposure Surgery (LES) Society, USA.
Correspondence: Dr K Chin, Less Exposure Surgery Specialists Institute (LESS Institute), $1100 \mathrm{~W}$. Oakland Park Blvd. Suite \#3, Fort Lauderdale, FL, 33311, USA. Email: kingsleychin@thelessinstitute.com 
pacientes, asociada a un aumento en el costo del sistema de salud. El paso a la cirugía ambulatoria va encaminado a reducir el costo general de la cirugía en conjunto y producir a la vez una mejoría en relación con la morbilidad de los pacientes. Los autores persiguen determinar la incidencia de la $I S Q$, así como los factores de riesgo asociados, en el contexto ambulatorio, obteniendo se ese modo una información valiosa para el cuidado general del paciente.

Métodos: Se revisaron las bases de datos de 2205 procedimientos espinales realizados durante 10 años por un solo cirujano. Se crearon dos grupos: el Grupo 1 formado por pacientes con procedimientos realizados en el recinto hospitalario, y el Grupo 2 formado por pacientes con procedimientos realizados en el centro de cirugía ambulatoria. Se excluyeron los casos de pacientes con menos de 18 años de edad, trauma agudo, o procedimientos ortopédicos menores. Se incluyeron lo casos de fusiones cervicales, reemplazo de disco, y descompresiones lumbares con o sin fusión. Los resultados evaluados incluyeron: edad, indice de masa corporal (IMC), tiempo de cirugía, y pérdida de sangre estimada (PSE). Los factores de riesgo relativo -- tales como indice de masa corporal, hábito de fumar, consumo de alcohol, y número de nivel espinal operado -- también fueron evaluados como factores de riesgo independientes de la ISQ.

Resultados: Se incluyeron 1010 casos: 642 en el contexto hospitalario, y 368 en el ambulatorio. La edad media y el IMC fueron $53 \pm 0.5$ años y $28.3 \pm 0.3 \mathrm{~kg} / \mathrm{m}^{2}$, respectivamente, sin ninguna significación intergrupal. Los tiempos quirúrgicos de $217 \pm 11$ minutos y $117 \pm 8$ minutos, y la PSE de 323 $\pm 33 \mathrm{~mL}$ y $73 \pm 8 \mathrm{~mL}$ tuvieron carácter significativo $(p=0.001)$ entre el grupo intrahospitalario y el ambulatorio. La incidencia general de la ISQ fue de 1.6\% y hubo diferencias significativas intergrupales, $\mathrm{p}=0.045$. La obesidad y las cirugías multiniveles resultaron para ser factores de riesgo independientes significativos, $\mathrm{p}=0.005$ y $\mathrm{p}=0.01$, respectivamente. El hábito de fumar tuvo el mayor riesgo relativo, 10.9, y fue también significativo, $\mathrm{p}=0.02$

Conclusión: La tasa de incidencia de ISQ en este estudio mostró diferencias significativas entre los contextos intrahospitalarios y ambulatorios. Deben tomarse en consideración los factores de riesgo modificables, tales como el peso, el hábito de fumar, el consumo de alcohol, y el número de niveles necesarios para la operación. Esto tendrá un impacto sobre la selección preoperatoria de los pacientes y el procedimiento requerido, a la vez que hará posible que disminuya el riesgo de ISQ.

Palabras claves: incidencia, intrahospitalario, cirugía de menos exposición, ambulatorio, infección del sitio quirúrgico

West Indian Med J 2017; 66 (3): 451

\section{INTRODUCTION}

The interest in outpatient spine surgery has surged in recent times. Improvements in technologies and refined surgical techniques have enabled major operations to be offered as less exposure surgery in free standing outpatient surgery centres. Currently, there are over 6000 free standing ambulatory surgery centres (ASCs) in the United States of America [USA] $(1,2)$ and this number is expected to grow exponentially. It is estimated that by 2016 greater than $50 \%$ of all spine surgeries will be done in an outpatient setting. Not surprisingly, this enthusiasm is fueled by reports of faster operations and patient recovery, fewer complications and reduced expenses seen by both patients and healthcare insurers $(3,4)$. Benefits to surgeons include a safer and more consistent operating team, reliable compensation and better patient outcomes $(5,6)$.

The literature is saturated with studies focussed on the feasibility, complication rates and patient-reported outcomes for a variety of procedures, most commonly cervical and lumbar decompression and fusion surgeries (7-14). However, there is a paucity of literature on the rate of postoperative surgical site infection (SSI) for cases performed in the ASCs as well as the risk factors associated with SSIs.
Surgical site infections are a devastating and leading cause of both nosocomial infections and unplanned hospital readmission in the USA, resulting in multiple operations, increased hospital stay and healthcare costs (15-17). The reported range of SSIs after adult inpatient elective spine surgery in the hospital setting is between $0.7 \%$ and $20 \%(18-22)$. Multiple risk factors have been identified which contribute to SSIs after spine surgery which include, increasing age, male gender, body mass index (BMI), metabolic derangements, co-morbidities, smoking and previous surgery $(18,23-27)$.

In order to substantiate its role in the future of spine surgery, ambulatory surgery centres must demonstrate at a minimum, equivalent and preferably decreased SSI rates than inpatient environments. Herein, a report is provided of the experience of outpatient spine surgery and rates of postoperative SSIs and how these results compare to similar surgeries performed in the hospital setting. The secondary aim was to evaluate the major risk factors for developing postoperative SSIs.

\section{SUBJECTS AND METHODS}

We reviewed 2205 spinal procedures from the database of a single spine surgeon between 2004 and 2014. Institutional 
review board (IRB) approval was granted for the cohort of patients in this study. The primary aim was to determine incidence of postoperative SSIs acquired in the outpatient setting after major elective spine surgeries and to compare this with a hospital cohort of patients of the same surgeon. We excluded patients younger than 18 years old, all acute traumatic cases from this study as well as patients with previous spine surgery, minor procedures including, epidural steroid injections, discograms and laser rhizotomies (total 1195). Standard aseptic techniques were maintained throughout each operation at all centres which were either Joint Commission for the Accreditation of Health Organizations (JCAHO) or Agency for Health Care Administration (AHCA) compliant in addition to standard prophylactic antibiotics. Major operations included were anterior cervical discectomy and fusion, cervical disc arthroplasty and lumbar decompression with or without fusion procedures (total 1010). Of the 1010 patients included in this study, 642 were operated on in the hospital setting (Group 1) and 368 in the ASCs setting (Group 2). Selection criterion for outpatient spine surgery (28) are summarized in Fig. 1.

1. Patient must be living or staying within 30 minutes of a hospital

2. $\mathrm{BMI}<1=42$

3. All patients with chronic medical illnesses must be stable and be cleared by their family practitioner and/or specialist where applicable

4. Patients with a history of heart disease must be cleared through cardiologist evaluation including echocardiogram and/or stress test

5. Patients must have a responsible adult living with, or staying with them, who is available to provide basic care and supervision for at least 24 hours after surgery

\section{Low-to-moderate anaesthesia risks (ASA Criteria 1 to 3)}

Fig 1: Inclusion criteria for outpatient spine surgery used in this study BMI; Body mass index

Outcome measures evaluated were; age, BMI, length of surgery (LOS), estimated blood loss (EBL), presence or absence of both superficial and deep wound infections postoperatively and comparison of incidence in single and multilevel procedures. Risk factors evaluated included: age $>65$ years $(29$ 31 ), gender (32), smoking status (29), alcohol use $(29,31)$, BMI $>30 \mathrm{~kg} / \mathrm{m}^{2}(33)$ and incidence in multilevel surgery [34] (Table 1).

\section{Statistical analysis}

Statistical analysis was performed using SPSS v22 (IBM corporation, New York, USA). An independent sample student $t$-test was used to compare groups for continuous data and Pearson's Chi-squared or Fisher exact test used categorical data. Continuous data comparisons were expressed as means with standard error. Relative risk (RR) and 95\% confidence intervals $(95 \% \mathrm{CI})$ were calculated for each of the categorical variables using univariate and multivariate analysis. Tests were considered significant if $p<0.05$.

\section{RESULTS}

A total of 1010 patients were evaluated. Group 1 comprised of 642 patients in the hospital setting and Group 2 comprised of 368 patients in the ASC. Females represented 52\% of patients overall, however, there was no statistical difference in gender between groups, $p=0.147$. Overall age and BMI was $53 \pm 0.5$ years and $28.3 \pm 0.3 \mathrm{~kg} / \mathrm{m}^{2}$, respectively. Mean age of Group 1 was $54 \pm 0.6$ years and Group 2 was $50 \pm 0.9$ years $(p=$ 0.270). Mean BMI for Groups 1 and 2 were $28.1 \pm 0.3 \mathrm{~kg} / \mathrm{m}^{2}$ and $28.8 \pm 0.4 \mathrm{~kg} / \mathrm{m}^{2}$, respectively, $p=0.724$. Demographic data are presented in Table 1.

Table. 1: Demographic data of sample population

\begin{tabular}{|c|c|c|c|c|c|}
\hline Age & $\begin{array}{c}n= \\
1010\end{array}$ & Percentage & Gender & $\begin{array}{l}n= \\
1010\end{array}$ & Percentage \\
\hline $18-39$ & 334 & $33 \%$ & Male & 485 & $48 \%$ \\
\hline $40-64$ & 450 & $45 \%$ & Female & 525 & $52 \%$ \\
\hline$>65$ & 220 & $22 \%$ & & & \\
\hline BMI & $\mathrm{n}=1010$ & & Alcohol & $\mathrm{n}=1010$ & \\
\hline $\begin{array}{l}\text { Underweight } \\
<18.5\end{array}$ & 71 & $7 \%$ & Yes & 586 & $58 \%$ \\
\hline $\begin{array}{l}\text { Normal } \\
18.5-24.9\end{array}$ & 293 & $29 \%$ & No & 424 & $42 \%$ \\
\hline $\begin{array}{l}\text { Overweight } \\
25-29.9\end{array}$ & 323 & $32 \%$ & Smoking & $\mathrm{n}=1010$ & \\
\hline $\begin{array}{l}\text { Obese } \\
30-34.9\end{array}$ & 202 & $20 \%$ & Yes & 576 & $57 \%$ \\
\hline $\begin{array}{l}\text { Morbid obese } \\
>35\end{array}$ & 121 & $12 \%$ & No & 434 & $43 \%$ \\
\hline $\begin{array}{l}\text { Number of } \\
\text { levels }\end{array}$ & $\mathrm{n}=1010$ & & & & \\
\hline Single level & 551 & $55 \%$ & & & \\
\hline Multilevel & 459 & $45 \%$ & & & \\
\hline
\end{tabular}

BMI; Body mass index 
Analysis of Groups 1 and 2 surgical times of $217 \pm 11$ minutes and $117 \pm 8$ minutes, respectively, revealed a statistically significant $(p=0.001)$ decrease in the outpatient group operative times. This was also true for estimated blood loss, Group 1 resulting with $323 \pm 33 \mathrm{~mL}$ lost and Group 2 with $73 \pm 8$ $\mathrm{mL}(p=0.001)$.

Overall incidence of postoperative SSI in both settings was 16 patients $(1.6 \%)$. In total, $88 \%$ occurred in the hospital setting and $12 \%$ in an outpatient setting. There were significantly less SSIs in the outpatient setting, $p=0.045$ as shown in Table 2. Of those, $75 \%$ were superficial and $25 \%$ were deep infections. One hundred per cent (4) of deep infections occurred in hospital cohort, $(p=0.383$, Table 2$)$.

Table: 2. Incidence of surgical site infection in each setting

\begin{tabular}{lllcl}
\hline & No SSI & SSI & Superficial & Deep \\
\hline Hospital & 628 & 14 & 10 & 4 \\
Outpatient & 366 & 2 & 2 & 0 \\
$p$-value & & 0.045 & & 0.383 \\
\hline
\end{tabular}

SSI; surgical site infection

Comparing cervical and lumbar cases, analysis revealed significance $(p=0.0001)$ between setting and total cases performed, however, there was no significance in incidence of SSIs between settings (Table 3 ).

Table: 3. Demographic of cervical and lumbar cases in each setting with infection incidence

\begin{tabular}{lllll}
\hline \multirow{2}{*}{ Spinal segment } & \multicolumn{2}{c}{ Total cases } & \multicolumn{2}{c}{ Infection } \\
& Cervical & Lumbar & Cervical & Lumbar \\
\hline Hospital & 204 & 438 & 5 & 9 \\
Outpatient & 202 & 166 & 0 & 2 \\
$p$-value & & 0.0001 & & 0.839 \\
\hline
\end{tabular}

There was a total of $385(60 \%)$ multilevel procedures performed in the inpatient group compared to $74(20 \%)$ in the outpatient group. There was significance between the number of single level procedures versus multilevel procedures performed in each setting, $p=0.0001$. Subgroup analysis of the number of levels operated on and SSIs revealed no significance, $p=0.468$ (Table 4 ).

Table: 4. Demographic of single and multilevel cases in each setting with infection incidence

\begin{tabular}{lllll}
\hline & \multicolumn{2}{c}{ Total cases } & \multicolumn{2}{c}{ Infection } \\
\hline Number of levels & Single & Multi & Single & Multi \\
Hospital & 257 & 385 & 3 & 11 \\
Outpatient & 294 & 74 & 0 & 2 \\
$p$-value & & 0.0001 & & 0.468 \\
\hline
\end{tabular}

Risk factor analysis included: age $>65$ years, gender, if patient smokes, use of alcohol, obesity $>30 \mathrm{~kg} / \mathrm{m}^{2}$ and multilevel surgery. Smoking, alcohol use, obesity and multilevel surgery proved to be significant risk factors. Of note obesity and smoking were the highest RR factors, $R R=9.3$ and 10.9, respectively. Findings are summarized in Table 5.

Table: 5. Risk factors for infection for spine surgery using univariate and multivariate analysis

\begin{tabular}{llll}
\hline $\begin{array}{l}\text { Risk factors for } \\
\text { infection }\end{array}$ & Relative risk & Confidence interval & $p$-value \\
\hline Age $>$ 65yeas & 2.1 & $0.76-5.67$ & 0.15 \\
Gender (Male) & 0.6 & $0.24-1.77$ & 0.84 \\
Smoker & 10.9 & $1.44-82.13$ & 0.02 \\
Alcohol use & 5.1 & $1.16-22.17$ & 0.03 \\
Obesity $>30 \mathrm{~kg} / \mathrm{m}^{2}$ & 9.3 & $2.65-32.41$ & 0.005 \\
Multilevel surgery & 5.2 & $1.5-18.14$ & 0.01 \\
\hline
\end{tabular}

The most common organism identified by culture and sensitivity was Staphylococcus aureus in 13 patients (hospital cohort 12, outpatient 1). The other three patients had growth $<105$ organisms. All superficial infections were treated with opening of the wound and healing by secondary intention whereas, all cases with deep infections had reoperation with implant removal.

\section{DISCUSSION}

This study aimed to directly compare the incidence of SSIs after spinal surgery in both the hospital and ambulatory surgery centre settings. Overall, there was a statistically significant difference in the incidence of SSIs occurring postoperatively between cohort groups. Superficial infections were more common than deep infections, which only occurred in the hospital group. This may be attributed to the significant decrease in operative time and blood loss in the outpatient group. Obesity, alcohol use and multilevel surgery were statistically significant risk factors and patients who smoked had the highest significant relative risk.

Surgical site infections are a major cause of morbidity and mortality for patients and are economic burden on the healthcare system $(35,36)$. It is important for surgeons to be aware of the risk factors, with the increasing number of ambulatory surgery centres offering outpatient spine surgery.

General classification of SSIs is divided into superficial, involving the skin incision and subcutaneous tissue and deep infections $(37,38)$. Clinical presentation for superficial infections involves pain, local tissue oedema and oozing of serosanguinous material, warmth, erythema and tenderness and usually occurs within two weeks of surgery. Deep infections may present similar to superficial over but usually develop after approximately six weeks to several months postoperatively.

The determination of SSI risk and risk factors has two important applications. First, accurate quantification of SSI risk is needed to compare SSI rates between patients groups. This can be determined by the setting of the operation, the service 
offered and the individual surgeon. Second, determining SSI risk for an individual patient is necessary to gauge the potential utility of preventive interventions (39).

Obese patients are at risk of having tissue necrosis in sutured wounds due, to an extensive layer of relatively avascular adipose tissue, which create a nidus for infection (40). Obesity has been shown to be an independent risk factor for both superficial and deep infections in previous studies (30, $35)$. The authors therefore advocate that, especially for outpatient spine surgery, a formal weight-loss programme should be in place for these patients as part of their management (35, 41) or patient selection be based on a predetermined eligibility criteria used $(28,42)$.

Although advanced age $(43,44)$ is believed to be a risk factor for SSI due, to the phenomenon of immunosenescence, whereby the body's immune system weakens with age, our study did not show a significant difference in age as a risk factor for SSI. However, for the purposes of ambulatory spine surgery, the authors advocate for surgery in patients' ages 18-80 years once they are deemed healthy and medically cleared by their primary care physician.

There is evidence to suggest that in a hospital setting, the incidence of postoperative infection of the lumbar intervertebral disc space is reduced, the less invasive the procedure (45). There is minimal evidence evaluating number of levels in a single procedure however, our study supported study by Ee et al (34), demonstrating that multilevel surgery is a risk factor for SSIs. Surgical site infections in multilevel procedures occurred at an incidence rate of $81 \%$ (13/16) compared to single procedures at $19 \%(3 / 16)$.

The use of surgical drains post spine surgery has been previously advocated to decrease wound complications (46-48). However, evidence-based guidance (49) as well as evidence showing a decrease in this rate once less exposure surgery techniques $(28,34,50)$ which limit dead space and the potential haematoma formation were instituted has led to a decline of this practice. No patients in the outpatient centre who had lumbar decompression with or without fusion had a lumbar drain in situ.

Several solutions have been proposed and tested to eliminate or at least reduce the incidence of this crippling complication such as ultra-clean airflow system, antibiotic-loaded allografts and standardizing prophylactic antibiotics (51-54). However, the most important modifiable risk factors identified in the literature inclusive of BMI, glycaemic control, smoking, alcohol abuse, duration of surgery and repeat surgery as part of staged procedures must be a prime target for surgeons operating in the ASC as the risk to the patient, surgeon and institution is magnified since patients are typically discharged within 24 hours of surgery, which may delay diagnosis and treatment of a developing SSI.

The authors report no biases or conflict of interest. The authors note the following strengths and limitations. The main strengths of this study are; sample size, random selection of patients based on inclusion criteria. The outcomes assessed include, patient and surgeon factors which were independently analysed. The variable of multiple surgeons was also controlled for since it was a single surgeon study.

Limitations of this study, which include: (1) a retrospective study (2) the absence of evaluation of patient metabolic factors before and after surgery, which are known to contribute to postoperative infection. Examples of these include poor nutritional status, as determined by serum albumin levels $<35 \mathrm{~g} / \mathrm{dL}$ and glycaemic status of diabetics in the study, (3) we did not consider medications known to impair wound healing such as steroids and those which hinder fusions such as NSAIDS, (4) the operating room used in both the hospital and outpatient groups varied although compliant and (5) baseline white blood cell counts were within range for preoperative assessment however, no postoperative analysis was performed. It would also be interesting to do follow-up prospective studies on SSIs in ambulatory centres.

In the outpatient setting, the authors recommend strict patient selection, extensive pre-operative counselling and explanation of the possibility for SSI in high-risk patients $\mathrm{w}$ ho failed to adequately modify their lifestyle through alcohol, smoking cessation, weight-loss and blood sugar control. From a surgeon's perspective, limiting the number of fusion levels, mandating strict aseptic techniques by all staff members (40, 55), ensuring prophylactic antibiotics, adopting instruments and surgical techniques which promote less exposure surgery, can all contribute to lowering the incidence of SSI after spine surgery in the ambulatory surgery centre.

\section{CONCLUSION}

The healthcare arena continues to expand with outpatient services being offered. This study has demonstrated a reduced incidence of SSIs in the outpatient setting compared to the hospital setting. Patients with risk factors such; as smoker, alcohol use and obesity should be carefully assessed to decrease this risk.

\section{AUTHORS' NOTE}

Conflicts of interest and sources of funding: We did not seek or receive any funding from the National Institutes of Health (NIH), Wellcome Trust, Howard Hughes Medical Institute (HHMI), or others for this work. Dr KR Chin is a shareholder in and receives other benefits from SpineFrontier Inc; none of the other authors (FJRP, CFP, NTB, AVC, RFD, or JAS) have any potential conflicts of interest to declare for this work

\section{REFERENCES}

1. Medicare Payment Policy: Report to the Congress. Washington, DC: MedPAC, 2014.

2. Homsted L. Institute of Medicine report: to err is human: building a safer health care system. The Florida Nurse 2000; 48: 6.

3. Pugely AJ, Martin CT, Gao Y, Mendoza-Lattes SA. Outpatient surgery reduces short-term complications in lumbar discectomy: an analysis of 4310 patients from the ACS-NSQIP database. Spine $2013 ; \mathbf{3 8}$ : 264-71.

4. Services U.S.D.o.H.a.H., Medicare Ambulatory Surgical Centre-Value Based Purchasing Implementation Plan. 2015.

5. Koenig L, Gu Q. Growth of ambulatory surgical centres, surgery vol- 
ume, and savings to medicare. Am J Gastroenterol 2013; 108: 10-5.

6. Hollenbeck BK, Hollingsworth JM, Dunn RL, Zaojun Y, Birkmeyer JD. Ambulatory surgery centre market share and rates of outpatient surgery in the elderly. Surg Innov 2010; 17: 340-5.

7. Barbagallo G, Certo F, Albanese V, Visocchi M. The impact of complications following cervical spine surgery: a systematic review. J Neurosurg Sci 2014; 58 (2 Suppl 1): 55-64.

8. Burneikiene S, Nelson EL, Mason A, Rajpal S, Villavicencio AT. The duration of symptoms and clinical outcomes in patients undergoing anterior cervical discectomy and fusion for degenerative disc disease and radiculopathy. Spine J 2015; 15: 427-32.

9. Buchholz AL, Morgan SL, Robinson LC, Frankel BM. Minimally invasive percutaneous screw fixation of traumatic spondylolisthesis of the axis. J Neurosurg Spine 2015; 22: 459-65.

10. Bydon M, Mathios D, Macki M, de la Garza-Ramos R, Sciubba DM, Witham TF et al. Long-term patient outcomes after posterior cervical foraminotomy: an analysis of 151 cases. J Neurosurg Spine 2014; 21: 727-31.

11. Mobbs RJ, Maharaj M, Rao PJ. Clinical outcomes and fusion rates following anterior lumbar interbody fusion with bone graft substitute i-FACTOR, an anorganic bone matrix/P-15 composite. J Neurosurg Spine 2014; 21: 867-76.

12. Park Y, Lee SB, Seok SO, Jo BW, Ha JW. Perioperative surgical complications and learning curve associated with minimally invasive transforaminal lumbar interbody fusion: a single-institute experience. Clin Orthop Surg 2015; 7: 91-6.

13. Shousha $\mathrm{M}$, Cirovic $\mathrm{D}$, Boehm $\mathrm{H}$. Infection rate after minimally invasive noninstrumented spinal surgery based on 4350 procedures. Spine 2015; 40: $201-5$.

14. Zhu Y, Zhang Y, Fang J, Xu G, Ye X. [Mid-term outcomes of unilateral pedicle screw fixation with lumbar interbody fusion for lumber degenerative diseases]. Zhonghua Yi Xue Za Zhi 2014; 94: 1326-9.

15. McCormack RA, Hunter T, Ramos N, Michels R, Hutzler L, Bosco JA. An analysis of causes of readmission after spine surgery. Spine 2012; 37: 1260-6.

16. Harrop JS, Styliaras JC, Ooi YC, Radcliff KE, Vaccaro AR, Wu C. Contributing factors to surgical site infections. J Am Acad Orthop Surg 2012; 20: $94-101$.

17. Gerometta A, Rodriguez Olaverri JC, Bitan F. Infections in spinal instrumentation. Int Orthop 2012; 36: 457-64.

18. Kasliwal MK, Tan LA, Traynelis VC. Infection with spinal instrumentation: Review of pathogenesis, diagnosis, prevention, and management. Surg Neurol Int 2013; 4 (Suppl 5): S392-403.

19. Nacke E, Ramos N, Stein S, Hutzler L, Bosco JA, 3rd. When do readmissions for infection occur after spine and total joint procedures? Clin Orthop Relat Res 2013; 471: 569-73.

20. Olsen MA, Nepple JJ, Riew KD, Lenke LG, Bridwell KH, Mayfield J et al. Risk factors for surgical site infection following orthopaedic spinal operations. J Bone Joint Surg Am 2008; 90: 62-9.

21. Abdul-Jabbar A, Takemoto S, Weber MH, Hu SS, Mummaneni PV, Deviren V et al. Surgical site infection in spinal surgery: description of surgical and patient-based risk factors for postoperative infection using administrative claims data. Spine 2012; 37: 1340-5.

22. Koutsoumbelis S, Hughes AP, Girardi FP, Cammisa FP Jr., Finerty EA, Nguyen JT et al. Risk factors for postoperative infection following posterior lumbar instrumented arthrodesis. J Bone Joint Surg Am 2011; 93: $1627-33$.

23. Fang A, Hu SS, Endres N, Bradford DS. Risk factors for infection after spinal surgery. Spine $2005 ; \mathbf{3 0}$ : $1460-5$.

24. Apisarnthanarak A, Jones M, Waterman BM, Carroll CM, Bernardi R, Fraser VJ. Risk factors for spinal surgical-site infections in a community hospital: a case-control study. Infect Control Hosp Epidemiol 2003; 24: 31-6.

25. Olsen MA, Mayfield J, Lauryssen C, Polish LB, Jones M, Vest J et al. Risk factors for surgical site infection in spinal surgery. J Neurosurg 2003; 98 (2 Suppl): 149-55.

26. Schimmel JJ, Horsting PP, de Kleuver M, Wonders G, van Limbeek J. Risk factors for deep surgical site infections after spinal fusion. Eur Spine J 2010; 19: 1711-9.
27. Veeravagu A, Patil CG, Lad SP, Boakye M. Risk factors for postoperative spinal wound infections after spinal decompression and fusion surgeries. Spine 2009; 34: 1869-72.

28. Chin KR, Coombs AV, Seale JA. Feasibility and patient-reported outcomes after outpatient single-level instrumented posterior lumbar interbody fusion in a surgery centre: preliminary results in 16 patients. 2015; 40: E36-42.

29. Pappou IP, Papadopoulos EC, Sama AA, Girardi FP, Cammisa FP. Post-operative infections in interbody fusion for degenerative spinal disease. Clin Orthop Relat Res 2006; 444: 120-8.

30. Pull ter Gunne AF, Cohen DB. Incidence, prevalence, and analysis of risk factors for surgical site infection following adult spinal surgery. Spine $2009 ; 34$ : 1422-8.

31. Gil-Egea MJ, Pi-Sunyer MT, Verdaguer A, Sanz F, Sitges-Serra A, Eleizegui LT. Surgical wound infections: prospective study of 4468 clean wounds. Infect Control 1987; 8: 277-80

32. Rao SB, Vasquez G, Harrop J, Maltenfort M, Stein N, Kaliyadan G et al. Risk factors for surgical site infections following spinal fusion proce-dures: a case-control study. Clin Infect Dis 2011; 53: 686-92.

33. Cheadle WG. Risk factors for surgical site infection. Surg Infect 2006; 7 (Suppl 1): S7-11.

34. Ee WW, Lau WL, Yeo W, Von Bing Y, Yue WM. Does minimally inva-sive surgery have a lower risk of surgical site infections compared with open spinal surgery? Clin Orthop Relat Res 2014; 472: 1718-24.

35. Pull ter Gunne AF, van Laarhoven CJ, Cohen DB. Incidence of surgical site infection following adult spinal deformity surgery: an analysis of patient risk. Eur Spine J 2010; 19: 982-8.

36. de Lissovoy G, Fraeman K, Hutchins V, Murphy D, Song D, Vaughn BB. Surgical site infection: incidence and impact on hospital utilization and treatment costs. Am J Infect Control 2009; 37: 387-97.

37. CDC. Surgical Site Infection (SSI) Event. Atlanta, GA: Centre of Disease Control and Prevention, 2015.

38. Sasso RC, Garrido BJ. Postoperative spinal wound infections. J Am Acad Orthop Surg 2008; 16: 330-7.

39. van Walraven C, Musselman R. The Surgical Site Infection Risk Score (SSIRS): A model to predict the risk of surgical site infections. PLoS One 2013; 8: e67167.

40. Hegde V, Meredith DS, Kepler CK, Huang RC. Management of postoperative spinal infections. World J Orthop 2012; 3: 182-9.

41. Walid MS, Robinson JS, Robinson ER, Brannick BB, Ajjan M, Robinson JS. Comparison of outpatient and inpatient spine surgery patients with regards to obesity, comorbidities and readmission for infection. $\mathrm{J}$ Clin Neurosci 2010; 17: 1497-8.

42. Hofer RE, Kai T, Decker PA, Warner DO. Obesity as a risk factor for unanticipated admissions after ambulatory surgery. Mayo Clinic Proceedings 2008; 83: 908-16.

43. Tenney JH, Vlahov D, Salcman M, Ducker TB. Wide variation in risk of wound infection following clean neurosurgery. Implications for perioperative antibiotic prophylaxis. J Neurosurg 1985; 62: 243-7.

44. Klein JD, Hey LA, Yu CS, Klein BB, Coufal FJ, Young EP et al. Perioperative nutrition and postoperative complications in patients undergoing spinal surgery. Spine 1996; 21: 2676-82.

45. Dauch WA. Infection of the intervertebral space following conventional and microsurgical operation on the herniated lumbar intervertebral disc. A controlled clinical trial. Acta Neurochir 1986; 82: 43-9.

46. Kou J, Fischgrund J, Biddinger A, Herkowitz H. Risk factors for spinal epidural hematoma after spinal surgery. Spine 2002; 27(15).

47. Scuderi GJ, Brusovanik GV, Fitzhenry LN, Vaccaro AR. Is wound drain-age necessary after lumbar spinal fusion surgery? Med Sci Monit 2005; 11: Cr64-6.

48. Walid MS, Abbara M, Tolaymat A, Davis JR, Waits KD, Robinson JS, III et al. The role of drains in lumbar spine fusion. World Neurosurg 77: 564-8.

49. Brown MD, Brookfield KF. A randomized study of closed wound suction drainage for extensive lumbar spine surgery. Spine 2004; 29: $1066-8$.

50. Andrew Glennie R, Dea N, Street JT. Dressings and drains in posterior spine surgery and their effect on wound complications. J Clin Neurosci

51. 2015; 22: 1081-7.

Gruenberg MF, Campaner GL, Sola CA, Ortolan EG. Ultraclean air for 
prevention of postoperative infection after posterior spinal fusion with instrumentation: a comparison between surgeries performed with and without a vertical exponential filtered air-flow system. Spine 2004; 29: 2330-4.

52. Borkhuu B, Borowski A, Shah SA, Littleton AG, Dabney KW, Miller F. Antibiotic-loaded allograft decreases the rate of acute deep wound infection after spinal fusion in cerebral palsy 2008; 33: 2300-4.

53. Nishant, Kailash KK, Vijayraghavan PV. Prospective randomized study for antibiotic prophylaxis in spine surgery: choice of drug, dosage, and timing. Asian Spine J 2013; 7: 196-203.

54. Mangram AJ, Horan TC, Pearson ML, Silver LC, Jarvis WR. Guideline for Prevention of Surgical Site Infection, 1999. Centres for Disease Control and Prevention (CDC) Hospital Infection Control Practices Advisory Committee. Am J Infect Control 1999; 27: 97-132.

55. Lister J. On the Antiseptic Principle in the Practice of Surgery. Br Med J $1867 ; 2: 246-8$. 